\title{
BALANCE AND CORE STABILIZATION TRAINING WITH EYES OPEN VERSUS EYES CLOSED IN YOUNG FOOTBALL PLAYERS
}

\author{
Rilind Obertinca, Vilma Dudonienė, Jūratė Požèrienė \\ Lithuanian Sports University
}

\begin{abstract}
Background. Core stability (or core strengthening) has become a well-known fitness trend that has started transcending into sports medicine. It has become a common practice to incorporate balance tasks into the training program for athletes who want to improve performance and prevent injuries.

Hypothesis. We suggest that core stabilization and balance training with closed eyes will be more effective than training with open eyes.

The aim of the study was to evaluate the effect of core stabilization training with open eyes versus closed eyes on balance and stability of young football players.

Methods. Fourteen healthy young football players aged 10-12 years were assessed for pre and post core stabilization training using two balance tests: Stork Balance Test (SBT) and Modified Star Excursion Balance Test (mSEBT), and one test for core stability - McGill Core Stability Test (MCST). The intervention included twelve twenty-minute training sessions each of them involved six core strengthening exercises. One group performed exercises with open eyes, and another with eyes closed.

Results. Core stability exercises with eyes closed as well as the same exercise done with eyes open insignificantly improved dynamic balance and core stability, but significantly improved the static balance of the subjects.

Conclusion. After applying training with closed eyes as well as eyes open, core stability and balance of young football players increased insignificantly. There were no significant differences in core stability and balance training between training with eyes open and eyes closed.
\end{abstract}

Keywords: core stabilization training, balance, open eyes, closed eyes.

\section{INTRODUCTION}

Football is a sport composed of several actions which require maintaining unilateral balance (Rouissi et al., 2006). Strong central body area decreases the risk of injury and provides explosive power in football players, improved higher rate anaerobic energy, and technical movements with and without the ball (Bloomfield et al., 2007).

Core stability (or core strengthening) has become a well-known fitness trend that has started transcending into sports medicine. Significant benefits of core stabilization have been touted, from improving athletic performance and preventing injuries to alleviating low back pain.

The core can be described as a muscular box with the abdominals in the front, paraspinals and gluteals in the back, the diaphragm as the roof, and the pelvic floor and hip girdle musculature as the bottom (Richardson et al., 1999). Enhancing 
core stability through exercise is common to musculoskeletal injury prevention programs (Huxel, Bliven, Anderson, 2013), and also core stabilization training have direct impact in the improvement of balance in professional football players (Kachanathu et al., 2014).

It has become a common practice to incorporate balance tasks into the training program for athletes who want to improve performance and prevent injuries (Kümmel et al., 2016). In biomechanics, balance is an ability to maintain the line of gravity (vertical line from centre of mass) of a body within the base of support with minimal postural sway (Shumway-Cook et al., 1988). Age-related physiologic changes in the eye may affect a person's balance. Vision is an important source of sensory input that specifies spatial orientation (Tinetti, 1987). Three main sensory systems-vision, vestibular and proprioception-are required for maintaining balance. Age-related changes occur in each system, but one of the more pronounced changes occurs with vision (Klein et al., 1996). It is hypothesized that with increasing age some individuals may rely more on vision than on vestibular and proprioceptive information for balance (Maki, McIlroy, 1996).

Children's development of postural stability using bilateral force plate measurements was described in few studies before 2006 (Lebiedowska, Syczewska, 2000; Hatzitaki et al., 2002; Lee et al., 2004; Nolan et al., 2005; Rival et al., 2005; Schmid et al., 2005), but none of these works incorporated reliability reports on the evaluation of the method of using force plate measurements for a childhood population. Interesting conclusions can be however taken from such studies, particularly from M. Schmid et al. (2005), focusing on 148 children with ages ranging from 7 to 11 . They showed that the role of vision varies within the studied age range, and that the maturation of balance control is not complete, even at the age of 11 .

In order to create good adult athletes, it is of primary importance that attention is paid to a complete and harmonic development of motor abilities at early ages, above all concerning the specific age-related ones in each phase of the athlete's body development. Presently, there is poor attention on such aspects, not only in practical training sessions, but also concerning the existing literature.

Few authors concentrated on the possible strategies to improve children's static and dynamic balance, and on the influence that different sport activities have on postural strategies at early ages. It is desirable that future research will focus on such aspects in order to clarify the underlying mechanisms and to develop new effective strategies for the expression of athletes' potential (Ricotti, 2011).

We hypothesize that core stabilization training with eyes closed would be more beneficial than training with eyes open.

The aim of this study was to evaluate the effect of core stabilization training with open eyes versus closed eyes on balance and stability of young football players. 
Balance and Core Stabilization Training With Eyes Open Versus Eyes Closed in Young Football Players

\section{METHODS}

Procedure. Balance and stability of fourteen football players aged 10-12 years were evaluated. The athletes had no restrictions from participation in their normal practice schedule or other activities during the course of the day. The experimental procedures and the risks involved were explained to all the subjects. All study procedures were approved by the LSU bioethics committee. Since all the participants were younger than 18 years of age, each participant signed an assent document and a legal guardian for each participant signed a parental consent form. Data collection was conducted inside the fieldhouse at a local football club.

All the subjects were handed a research information sheet and given the option to withdraw at any time from the study. Two athletes quit the study due to absence at least in one training session.

Subjects. All The subjects $(\mathrm{n}=14)$ were randomly divided into two homogenous groups (Table 1): training group with eyes open (EOT), and training group with eyes closed (ECT).

Because of drop-out of two subjects, results of only 12 players are presented.

Table 1. The height and body weight of players involved in the study

\begin{tabular}{|l|c|c|c|}
\hline \multirow{2}{*}{\multicolumn{1}{|c|}{ Characteristics }} & \multicolumn{2}{|c|}{ Group } & \multirow{2}{*}{ p-value } \\
\cline { 2 - 3 } & $\begin{array}{c}\text { Players CET } \\
(\mathbf{n}=\mathbf{6})\end{array}$ & $\begin{array}{c}\text { Players OET } \\
(\mathbf{n}=\mathbf{6})\end{array}$ & \\
\hline Height $(\mathrm{cm})$ Mean \pm SD & $152.5 \pm 6.1$ & $148.2 \pm 3.6$ & \multirow{2}{*}{$\mathrm{p}=0.162$} \\
\hline Rank & $148-164$ & $144-154$ & \\
\hline Weight $(\mathrm{kg})$ Mean \pm SD & $40.2 \pm 4.4$ & $36.5 \pm 2.9$ & \multirow{2}{*}{$\mathrm{p}=0.121$} \\
\cline { 1 - 3 } Rank & $36-48$ & $32-40$ & \\
\hline
\end{tabular}

Measurements. Young football players were assessed twice: before and after intervention. Balance of subjects was assessed with two balance tests: Stork Balance Test (SBT) and Modified Star Excursion Balance Test (SEBT).

Core Stability was assessed using stability tests according to S. McGill (2015) and included four tests: Trunk Flexor and Extensor Endurance test, and The Lateral (Right and left sides) Trunk Endurance Test.

Intervention. The intervention included twelve training sessions (three times a week for one month) each of them involved six core strengthening exercises with twenty-minute sessions after 15 min warm up, three times a week, for four weeks. All exercises were performed with three repetitions, including 30 seconds rest between repetitions and one-minute rest between exercises. 


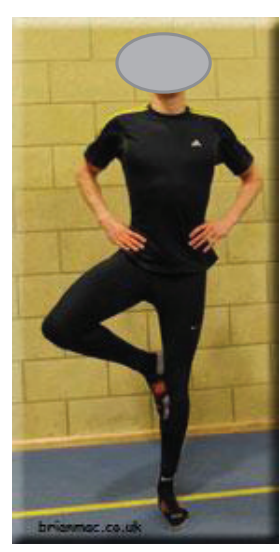

1a

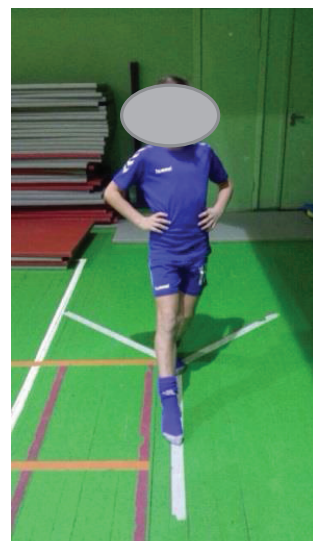

$1 \mathrm{~b}$

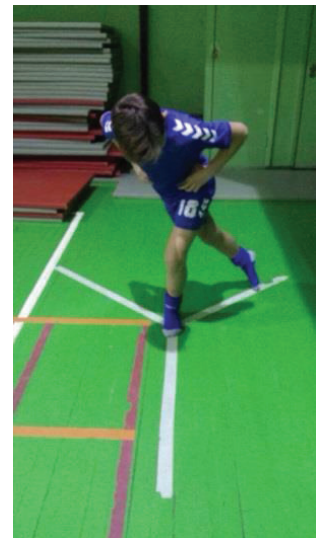

$1 \mathrm{c}$

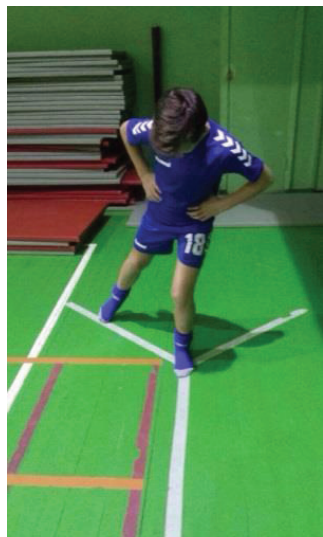

$1 d$

Figure 1. Stork Balance Test (1a) and Modified Star Excursion Balance Test, 1b) Anterior, 1c) Posteromedial, and 1d) Posterolateral

Subjects were instructed to wear their regular shoes during the testing and training sessions.

The balance activities included: Single Leg Stance (A), Bridging (B), Back Extension (C), Table top Crunch (D); Airplane (E), and Straight Arm Plank (F) (Figure 2).

Players of both group performed the same exercises with the same sequence and duration, only one group with eyes closed, another - with eyes open.

\section{Statistical Analyse}

All quantitative variables that followed normal distraction was expressed as mean \pm standard deviation (SD). Differences in baseline characteristics between the two groups (unpaired t-test) and between pre and post intervention (a repeatedmeasures t-test) were assessed using t-test. Difference across groups were considered statistically significant when $\mathrm{p}<0.05$.

\section{RESEARCH RESULTS}

The groups were homogeneous for age, weight, height, time of practice and training sessions per week. Results of Modified Star excursion balance test of the players standing on Left Leg are presented in Table 2. 


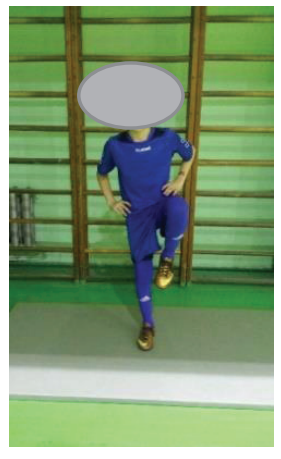

A

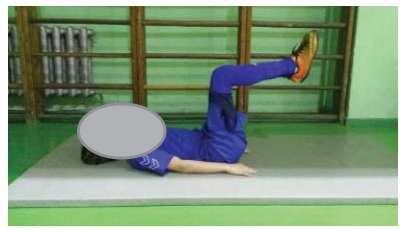

$\mathrm{D}$

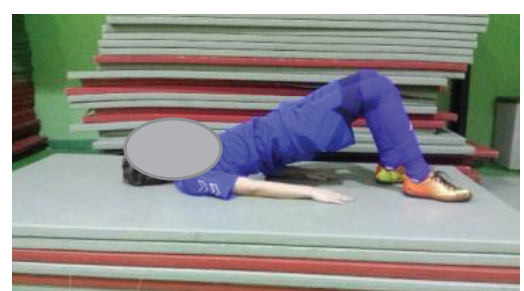

B

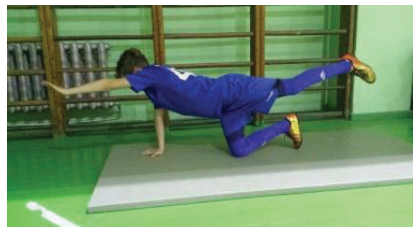

$\mathrm{E}$

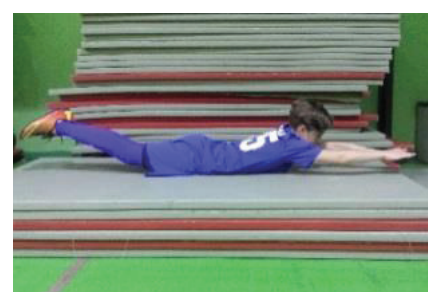

$\mathrm{C}$

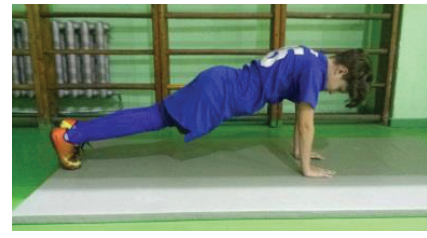

$\mathrm{F}$

Figure 2. The balance activities: Single Leg Stance (A), Bridging (B),

Back Extension (C), Tabletop Crunch (D); Airplaning (E), and Straight Arm Plank (F)

Table 2. Results of Star Excursion Balance Test on Left leg (SEBT) in eyes closed training (ECT) and eyes open training (EOT) groups

\begin{tabular}{|c|c|c|c|}
\hline \multirow[b]{2}{*}{ SEBT left $(\mathrm{cm})$} & \multicolumn{2}{|c|}{ Group Players } & \multirow{2}{*}{$\begin{array}{c}\text { p-value } \\
\text { between } \\
\text { groups }\end{array}$} \\
\hline & $\begin{array}{c}\text { ECT } \\
(n=6)\end{array}$ & $\begin{array}{c}\text { EOT } \\
(n=6)\end{array}$ & \\
\hline \multicolumn{4}{|c|}{ Anterior } \\
\hline Before training & $76.0 \pm 3.9$ & $69.7 \pm 4.0$ & $\mathrm{p}=0.009$ \\
\hline After training & $78.8 \pm 4.7$ & $73.3 \pm 3.8$ & $\mathrm{p}=0.049$ \\
\hline \multicolumn{4}{|c|}{ Posteromedial } \\
\hline Before training & $76.8 \pm 4.6$ & $72.5 \pm 3.8$ & $\mathrm{p}=0.050$ \\
\hline After training & $80.0 \pm 5.6$ & $76.2 \pm 4.1$ & $\mathrm{p}=0.205$ \\
\hline \multicolumn{4}{|c|}{ Posterolateral } \\
\hline Before training & $76.2 \pm 4.6$ & $70.5 \pm 3.4$ & $\mathrm{p}=0.056$ \\
\hline After training & $79.5 \pm 4.7$ & $73.8 \pm 2.9$ & $\mathrm{p}=0.037$ \\
\hline
\end{tabular}

Results of Modified Star excursion balance test of the players standing on Right Leg are presented in Table 3. 
Table 3. Results of Star Excursion Balance Test on Right leg (SEBT) in eyes closed training (ECT) and eyes open training (EOT) groups

\begin{tabular}{|l|c|c|c|}
\hline \multirow{2}{*}{ SEBT right (cm) } & $\begin{array}{c}\text { CET } \\
(\mathbf{n = 6 )}\end{array}$ & $\begin{array}{c}\text { Group } \\
\text { p-value } \\
\text { between } \\
\text { groups }\end{array}$ \\
\cline { 2 - 4 } & \multicolumn{3}{|c|}{ Anterior } \\
\hline Before training & $76.2 \pm 4.3$ & $69.3 \pm 2.2$ & $\mathrm{p}=0.006$ \\
\hline After training & $80.7 \pm 4.6$ & $74.2 \pm 1.8$ & $\mathrm{p}=0.009$ \\
\hline \multicolumn{4}{|c|}{ Posteromedial } \\
\hline Before training & $76.8 \pm 4.7$ & $71.5 \pm 2.4$ & $\mathrm{p}=0.033$ \\
\hline After training & $80.7 \pm 6.2$ & $74.8 \pm 1.8$ & $\mathrm{p}=0.050$ \\
\hline \multicolumn{4}{|c|}{ Posterolateral } \\
\hline Before training & $75.5 \pm 4.2$ & $69.5 \pm 2.7$ & $\mathrm{p}=0.014$ \\
\hline After training & $77.3 \pm 5.7$ & $72.2 \pm 1.5$ & $\mathrm{p}=0.056$ \\
\hline
\end{tabular}

Results of Stork balance test increased significantly in both groups (Table 4.), but there were no statistical differences between groups before and after intervention.

Table 4. Results of Stork Balance test with Right and Left Leg of the players

\begin{tabular}{|l|c|c|c|}
\hline \multirow{2}{*}{ Stork balance test } & \multicolumn{2}{|c|}{$\begin{array}{c}\text { Group } \\
\text { between } \\
\text { groups }\end{array}$} \\
\cline { 2 - 4 } & \multicolumn{4}{|c|}{$\begin{array}{c}\text { Closed eyes } \\
(\mathbf{n}=\mathbf{6})\end{array}$} & $\begin{array}{c}\text { Open eyes } \\
(\mathbf{n}=\mathbf{6})\end{array}$ & $\mathrm{p}=0.309$ \\
\hline Before training & $33.2 \pm 21.7$ & $43.3 \pm 15.9$ & $\mathrm{p}=0.317$ \\
\hline After training & $102.2 \pm 68.6^{*}$ & $70.3 \pm 28.3^{*}$ & $\mathrm{p}=0.919$ \\
\hline \multicolumn{4}{|c|}{ Left Leg } \\
\hline Before training & $40.3 \pm 32.6$ & $38.7 \pm 22.0$ & $\mathrm{p}=0.941$ \\
\hline After training & $105.7 \pm 77.8^{*}$ & $108.5 \pm 49.2^{*}$ & \\
\hline
\end{tabular}

Note. $*-p<0.05$, comparing results before and after intervention.

Our intervention had effect only on one test of core stability tests (Table 5). 
Balance and Core Stabilization Training With Eyes Open Versus Eyes Closed in Young Football Players

Table 5. McGill Core Stability Test results of the players involved in the study

\begin{tabular}{|l|c|c|c|}
\hline \multirow{2}{*}{$\begin{array}{l}\text { McGill Core } \\
\text { Stability Tests }\end{array}$} & $\begin{array}{c}\text { Players CET } \\
(\mathbf{n = 6 )}\end{array}$ & $\begin{array}{c}\text { Players OET } \\
(\mathbf{n = 6 )}\end{array}$ & $\begin{array}{c}\text { p-value } \\
\text { between } \\
\text { groups }\end{array}$ \\
\hline \multicolumn{5}{|c|}{ Trunk flexors } \\
\hline Before training & $63.0 \pm 31.8$ & $52.8 \pm 20.1$ & $\mathrm{p}=0.522$ \\
\hline After training & $89.8 \pm 60.0 *$ & $60.7 \pm 39.3 *$ & $\mathrm{p}=0.342$ \\
\hline \multicolumn{5}{|c|}{ Trunk extensors } \\
\hline Before training & $58.7 \pm 29.1$ & $65.7 \pm 31.9$ & $\mathrm{p}=0.699$ \\
\hline After training & $58.3 \pm 19.9$ & $65.0 \pm 34.3$ & $\mathrm{p}=0.840$ \\
\hline \multicolumn{7}{|r|}{ RSB + LSB } \\
\hline Before training & $66.2 \pm 33.0$ & $66.8 \pm 15.4$ & $\mathrm{p}=0.965$ \\
\hline After training & $63.2 \pm 43.8$ & $64.0 \pm 49.0$ & $\mathrm{p}=0.455$ \\
\hline
\end{tabular}

Note. RSB - right Side Bridge, LSB - left Side Bridge.

\section{DISCUSSION}

The primary purpose of this study was to evaluate effect of core stabilization training with eyes open versus eyes closed on the balance and lumbar stability of young football players.

Scientific literature states that balance and coordination emerge as key trainable motor skills from the age of 10, raising the attention on the importance of specific equilibrium and coordination-based training sessions at that age (Ricotti, 2011). The core becomes activated before gross body movements as part of the postural control system. Since the core is responsible for postural control, assessments of dynamic balance are alternative to assess core stabilization.

The current study did not find statistical differences in static and dynamic balance between two groups. The Static Balance was measured with Stork Balance Test, and our results show that even static balance improved in both groups, but there were no significant differences between groups.

The Dynamic Balance was measured with Modified Star Excursion Balance Test (three directions). Our measurement of dynamic balance with Modified Star Excursion Balance Test presents potential areas of weakness. The Modified Star Excursion Balance Test does seem to be a good test for screening the balance, however, for pre-testing and post-testing of young (10-12) subjects multiple variables exist which could lead to incorrect data, with the main one of difficulties in understanding the procedure of testing from the kids. On the other hand, possible strong point of our study is subject selection. All subjects were part a very professional football club, with regular and professional training sessions for their age. All subjects started playing football at the age of 5-6, and all of them were 
in amazing shape in training and games, which directly had a big impact on our intervention time, they always did all exercises without hesitation and were very motivated.

Our findings suggest that it is possible to improve a person's balance through core stabilization training in twelve training sessions but there was no significant difference between two groups: in players who trained with open eyes (EOT) versus players who trained with closed eyes (CET). However, one of the factors of getting not significant results may be small group of participants.

Possible weaknesses of our study may be described in two broad categories: number of participants and randomisation, and another - chosen exercises for stability training.

The first area of weakness is division of subjects into groups. Based in other research, the dividing into two groups was random, which even before intervention gave us some significant differences in the results between the groups. So, in the future, studies with bigger numbers of participants should be performed and not even body measurements (as body weight and height) should be similar, but measurements at baseline should be similar.

Common stabilization exercises for core stability are: Supine Bridge (1), Side Bridge (2), Plank (3), Bird Dog (4), and Supine Unilateral Bridge (5) (Huxel, Bliven, Anderson, 2013). A lack of consensus exists about the most effective exercises for optimizing core stability. Exercises chosen by us might have not produced the expected effect on the outcomes.

There is a disagreement in the number of sessions, weeks and days needed to obtain satisfactory results. The weakness of our study might be that the duration of intervention was too short. In addition, future studies could include longer time interventions to determine how long the improvement in balance is sustained. Another consideration would be to monitor if improvements in balance correlate to a decrease in the number of their future injuries.

The study done by L. R. Heleno et al. (2016) demonstrated significant improvement after five weeks, which facilitated the prevention of injuries and accelerated the rehabilitation of athletes, since championship timetables did not allow the application of long-term preventive or functional performance improvement programs.

Finally, our results do not support our hypothesis that balance training in players will be more effective if done with eyes closed. As opposite to our hypothesis, our results matched with the results from the similar study (Carpenter et al., 2001), but done with old patients. 
Balance and Core Stabilization Training With Eyes Open Versus Eyes Closed

in Young Football Players

\section{CONCLUSIONS}

In the present study, there were no statistically significant differences in static and dynamic balance and trunk stability measures between young football players trained for four weeks with open and closed eyes.

\section{REFERENCES}

Bloomfield, J., Polman, R., O’Donoghue, P. (2007). Physical demands of different positions in FA Premier League soccer. Journal of Sports Science \& Medicine, 6 (1), 63.

Carpenter, C., Stanford, M., Putnam, K. (2001). A comparison of eyes open versus eyes closed balance training. Capstone Project 5-1-2001, Pacific University.

Hatzitaki, V., Zlsi, V., Kollias, I., Kioumourtzoglou, E. (2002). Perceptual-motor contributions to static and dynamic balance control in children. Journal of Motor Behavior, 34 (2), 161-170. doi: 10.1080/00222890209601938

Heleno, L. R., da Silva, R. A., Shigaki, L. et al. (2016). Five-week sensory motor training program improves functional performance and postural control in young male soccer players - A blind randomized clinical trial. Physical Therapy in Sport, 22, 74-80.

Huxel Bliven, K. C., Anderson, B. E. (2013). Core stability training for injury prevention. Sports Health, 5 (6), 514-522.

Kachanathu, S. J., Tyagi, P., Anand, P., Hameed, U. A., Algarni, A. D. (2014). Effect of core stabilization training on dynamic balance in professional soccer players. Physikalische Medizin, Rehabilitationsmedizin, Kurortmedizin, 24 (06), 299-304.

Klein, R., Klein, B. E., Lee, K. E. (1996). Changes in visual acuity in a population: The Beaver Dam Eye Study. Ophthalmology, 103 (8), 1169-1178.

Kümmel, J., Kramer, A., Giboin, L. S., Gruber, M. (2016). Specificity of balance training in healthy individuals: A systematic review and meta-analysis. Sports Medicine, 46 (9), 1261-1271.

Lebiedowska, M. K., Syczewska, M. (2000). Invariant sway properties in children. Gait \& Posture, 12 (3), 200204. doi: 10.1016/S0966-6362(00)00080-1

Lee, H. Y., Cherng, R. J., Lin, C. H. (2004). Development of a virtual reality environment for somatosensory and perceptual stimulation in the balance assessment of children. Computers in Biology and Medicine, 34 (8), 719-733.

Maki, B. E., McIlroy, W. E. (1996). Postural control in the older adult. Clinics in Geriatric Medicine, 12 (4), $635-658$.

McGill, S. M. (2015). Low Back Disorders, 3E. Human Kinetics.

Nolan, L., Grigorenko, A., Thorstensson, A. (2005). Balance control: Sex and age differences in 9-to 16-year-olds. Developmental Medicine and Child Neurology, 47 (7), 449-454. doi: 10.1017/S0012162205000873

Richardson, C., Jull, G., Hides, J., Hodges, P. (1999). Therapeutic Exercise for Spinal Segmental Stabilization in Low Back Pain (pp. 992-1001). London: Churchill Livingstone.

Ricotti, L. (2011). Static and dynamic balance in young athletes. Journal of Human Sport and Exercise, 6 (4), 616-628.

Rival, C., Ceyte, H., Olivier, I. (2005). Developmental changes of static standing balance in children. Neuroscience Letters, 376 (2), 133-136. doi: 10.1016/j.neulet.2004.11.042

Rouissi, M., Chtara, M., Owen, A. et al. (2016). Effect of leg dominance on change of direction ability amongst young elite soccer players. Journal of Sports Sciences, 34 (6), 542-548.

Schmid, M., Conforto, S., Lopez, L., Renzi, P., D’Alessio, T. (2005). The development of postural strategies in children: A factorial design study. Journal of NeuroEngineering and Rehabilitation, 2 (1), 29. doi: 10.1186/1743-0003-2-29

Shumway-Cook, A., Anson, D., Haller, S. (1988). Postural sway biofeedback: Its effect on re-establishing stance stability in hemiplegic patients. Archives of Physical Medicine and Rehabilitation, 69 (6), 395-400.

Tinetti, M. E. (1987). Factors associated with serious injury during falls by ambulatory nursing home residents. Journal of the American Geriatrics Society, 35 (7), 644-648. 


\section{JAUNŲ FUTBOLO ŽAIDĖJŲ PUSIAUSVYROS \\ BEI STABILUMO LAVINIMO SKIRTUMAI \\ ATLIEKANT PRATIMUS ATSIMERKUS IR UŽSIMERKUS}

\section{Rilind Obertinca, Vilma Dudonienė, Jūratė Požèrienė}

Lietuvos sporto universitetas

\section{SANTRAUKA}

Tyrimo pagrindimas. Liemens stabilumas (ar liemens stiprinimas) darosi vis populiaresne sveikatinimo kryptimi, persikeliančia ị sporto medicinos pasaulį. Jau įprasta pusiausvyros lavinimo užduotis įtraukti ị treniruočių programas, norint pagerinti sportinę veiklą ir išvengti sužalojimų.

Hipoteze. Manome, kad liemens stabilumo ir pusiausvyros lavinimas atliekant pratimus užsimerkus bus veiksmingesnis nei atsimerkus.

Tikslas - nustatyti liemens stabilumo lavinimo pratimų, atliekamų atsimerkus ir užsimerkus, poveikį.

Metodai. Keturiolika sveikų jaunų futbolo žaidèjų (10-12 metų amžiaus) buvo ìvertinti prieš intervenciją ir po jos, naudojant „Gandro“ testą, „Žvaigždès nuokrypio" testą ir stuburo stabilumo testus pagal McGill. Dvylika dvidešimties minučiu trukmès stabilumo ir pusiausvyros lavinimo treniruočių (atliekant šešis stabilumo lavinimo pratimus) buvo skirta tiriamiesiems, kurie atsitiktinès atrankos būdu buvo suskirtstyti ị dvi grupes. Vienos grupès tiriamieji atliko pratimus atsimerkę, kitos - užsimerkę.

Rezultatai. Stuburo stabilumo lavinimo pratimai, atliekami atsimerkus, kaip ir užsimerkus, nereikšmingai pagerino tiriamųjų dinaminę pusiausvyrą, stuburo stabilumą, reikšmingai - tiriamưjų statinę pusiausvyrą.

Išvada. Tiek atliekant pratimus užsimerkus, tiek atsimerkus, tiriamųų stabilumas ir pusiausvyra pagerejo, tačiau nenustatyta skirtumų tarp rodiklių, atliekant pratimus užsimerkus ir atsimerkus.

Raktažodžiai: liemens stabilumo lavinimas, pusiausvyra, pratimai, atliekami atsimerkus ir užsimerkus. 